\section{Universities for Reform}

THE first private meeting on November 17 of the Academic Advisory Committee organized by the Committee of Vice-Chancellors seems to have been not merely a success but a landmark in the development of relations between British universities and British schools. One of the participants said afterwards that he had been astonished. "I had not expected anything like this." The outstanding feature of the proceedings seems to have been the unanimous agreement that the basis for selection into universities must be changed. In the process, the proposals put forward by the Schools Council for changing the present system seem not to have found many supporters.

Those present at the meeting in the Senate House of the University of London included most of the vicechancellors of the British universities as well as academics nominated by the university senates. The chairman was Dr D. G. Christopherson, chairman of the Committee of Vice-Chancellors, and the audience ran to about 100. The proceedings were opened by $\mathrm{Dr}$ Geoffrey Templeman, Vice-Chancellor of the University of Kent and a member of the Schools Council, who described the origins of the Schools Council's proposal for a reform of the sixth form curriculum. A document embodying these proposals has already been circulated to the universities and will be published in the near future. The nub of the scheme is that the externally examined studies of a sixth form pupil should be restricted to two Advanced level subjects, and that there should be internally moderated courses (called "electives") as well.

The surprise at Friday's meeting seems to have been the way in which the principal speakers, like those who followed them from the floor, argued in favour of a broader curriculum and against what seemed to them to be the narrowing character of the proposals of the Schools Council. The ball was set rolling, from the platform, by Professor J. T. Allanson of the University of Birmingham, who argued that the preparation at school for a scientific education should be more liberal; he would see the present pattern of three A-levels broadened to include at least four courses in the sixth form. Professor J. G. Wilson followed next, with the argument that the pattern of entrance to universities determined by performance in three A-level courses is one of the reasons for the drift from science to the arts subjects; in his view, too, the Schools Council's scheme would hinder and not help. The same theme seems to have been echoed at the conference by $\mathrm{Mr} \mathrm{J}$. Morrison, Principal of University College, Cambridge, who argued instead in favour of a pattern of five courses in the sixth form, spanning the arts and the sciences. By all accounts, this was very much like the scheme which Mr Morrison described at the Cambridge conference reported in Nature on September 23, 1967.

One experienced and philosophical observer of discussions among university representatives on academic policy said after the meeting that it was a great surprise that "not one voice was raised against the general character of the objections against the Schools Councils' proposals". The general opinion seems to have been one of sympathy with the objectives of the Schools Council, but scepticism about its methods. Dr F. S.
British universities seem prepared for change in entrance requirements.

Dainton, Vice-Chancellor of the University of Leicester. is known to have supported Professor Wilson's argument. Vice-Chancellors Aitken, Swann and Edwards (of Birmingham, Edinburgh and Broadford) are known to have intervened in favour of a broadened curriculum. Lord Annan (né Noel Annan) seems to have come out on the side of the angels in a characteristically impish way.

Professor Bryan Thwaites argued strongly at the conference for a course in mathematics designed for all students in British sixth forms. By all accounts, Professor Thwaites's proposals have already been put to the Schools Council, but the appropriate committees seem so far to have been unable to resolve the differences between the pure and the not-so-pure mathematicians, with the result that the council has not yet embarked on the development of the appropriate curriculum. The view at the meeting seems to have been that if compulsion of any kind is to be imposed on students leaving British schools, courses in mathematics and English should be obligatory.

What will this mean for the universities? One view, championed by Professor L. R. B. Elton (University of Surrey), was that the universities should somehow be able to accommodate more liberally educated entrants within their present three-year pattern of undergraduate courses. There seemed, however, to be more support for the notion that a more liberal sixth form would bring with it the need for four year courses. On this occasion, the universities seem to have been less readily disposed than on previous occasions to assume that such a development is unthinkable on financial grounds.

The day's discussion seems, by all accounts, to have been splendidly capped by a stirring speech from Professor C. C. Butler (Imperial College), who urged the need for reform and the need for an evolutionary approach to it. He did not think that the British system could be made to change overnight, and he urged that the universities should collaborate with the schools in a number of experiments designed to test the feasibility and the advantages of different patterns of entrance qualifications. What he has in mind, by all accounts, is a series of experiments in which selected groups of schools would be encouraged to embark on alternative patterns of sixth form work in return for an undertaking by the universities that pupils so involved would not be handicapped in seeking entrance to universities.

But a heady day plotting reform does not mean that everything will now be different. For one thing, there is no certainty that the opinions of the university representatives last week will be confirmed by university senates, which are being asked by the ViceChancellors' Committee to submit their first comments on the proposals of the Schools Council by the end of this year. Early in the new year there is likely to be a discussion within the Standing Conference on Entrance to Universities from which, with luck, there may emerge a co-ordinated university view to put to the Schools Council by the spring of 1968. On the present showing, it seems very much as if this reply will take the form of an alternative proposal. 